Military Technical College

Kobry El-Kobbah, Cairo, Egypt

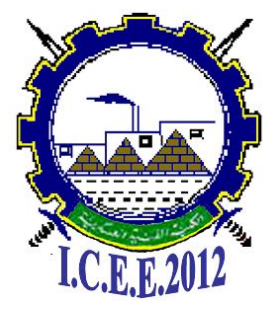

$6^{\text {th }}$ International Conference on

Chemical \& Environmental Engineering

29 -31 May, 2012.

CEEB-4

\title{
REMOVAL OF CHROMIUM IONS FROM INDUSTRIAL WASTE EFFLUENTS BY ADSOPTION
}

\author{
Dr. Eman A. Ashour* and Dr. M. Zakaria Abdel-Wahhab*
}

\begin{abstract}
Heavy metals are unacceptable pollutants if present in industrial or urban wastes, due to their highly toxic effects for humanity. Chromium ions, especially if in the hexavalent form, are one of these undesirable waste contents. They may be present in industrial solid or liquid effluents, especially those from tanneries and dyeing plants, which will appear finally in the effluent liquids, and perhaps solids. The objective of the present investigation is to remove chromium ions, by the adsorption technique, from liquid and/or solid effluents in order that these may be safely disposed in rivers, canals or draining exits. Chicken feathers, were chosen to be the solid adsorbent. This will decrease land environmental pollution by feathers and will remove chromium ions from liquid wastes, as well. The factors affecting the removal process were examined such as equilibrium time, feather charges, mixing conditions and the $\mathrm{pH}$ of the waste solution. The best results were obtained at 1 and 2 values of the $\mathrm{pH}$. Equilibrium modeling has been carried out using Langmuir, Freundlish and Redlish- Peterson models. The correlation between the three isotherms and experimental data was found to be reasonable in all cases. A simple kinetic model has been developed to explain the external mass transport of chromium from water onto chicken feathers and determine the external mass transfer coefficient, $K_{s}$ under influence of a number of design variables, namely agitation seep, size and mass of chicken feathers. By log-log correlation, it has been proved that $\mathrm{K}_{\mathrm{s}}$ varies linearly with agitation, size and mass of chicken feathers.
\end{abstract}

Key words: $\mathrm{Cr}$ (VI); adsorption; chicken feathers; adsorption isotherms.

\footnotetext{
${ }^{*}$ Dept. of Chem. Eng., Fac. Of Eng., Minia University, Minia, Egypt
} 


\section{1- Introduction}

The presence of heavy metals in drinking water is unacceptable due to their elevated rate of toxicity for living organisms. The presence of such metals in wastewater, from industrial or urban sources, limits the free disposal of such water due to their unconformance to environmental legislations of wastewater disposal. Due to that reason and many sanitary others, the water containing such metals were subjected to physico-chemical methods [1-3], biological methods [4-6] and/ or recent non-traditional methods [7-9] of treatments. In that respect, chromium ions are of special interest due to the abundant use of chromium salts in a lot of industrial activities, especially in tanneries and dyeing plants.

Egyptian limits for total chrome in liquid effluents reach about one milligram per liter, while the average tannery raw waste water content may reach 4.9 kilogram per ton of raw hides processed in the total chrome content. When concentration of chromium reaches $0.1 \mathrm{mg} / \mathrm{g}$ body weight, it can ultimately become lethal [10]. Currently the most common processes for elimination are adsorption, reverse osmosis and chemical reactions that involve reduction and precipitation. Among them adsorption has been shown as a feasible alternative method for removing traces of chromium from wastewater [10-12]. In this regard the use of abundant low cost and effective adsorbent materials is of interest. Activated carbon has been recognized as a highly effective adsorbent for the treatment of heavy metals in wastewater [13]. However, it is relatively expensive to produce. Therefore, efforts are being directed towards finding efficient and low cost adsorbent materials. A variety of low cost materials like fly ash $[14,15]$, wood charcoal [16] bituminous coal [17], bagasse and coconut jute [18], rice husk carbon [19], peat [20], red mud [21], used black tea leaves [22], activated carbon from sugar industrial waste[23], sugar cane bagasse [24] and many others have been tried [25-28]

In the course of the present investigation, and following the main objective of searching for local, abundant and economic adsorbents, one of the daily abundant solid wastes is tested for its feasibility as adsorbent for removal of chromium ions from liquid effluents and wastes; that is the chicken feathers. The factors affecting the removal process were examined and the adsorption data were studied and modelized.

\section{2-EXPERMENTAL}

Raw chicken feathers were washed with a detergent, rinsed several times with distilled water and then left to dry at room temperature. The dried feathers were cut to pieces in the range $0.5-2.0 \mathrm{~cm}$ length and then used in the sorption tests.

Adsorption experiments were carried out using batch equilibrium technique. Initial concentrations were prepared in the range 5-50 ppm. A series of 100-ml Erlenmeyer's flasks containing $0.1 \mathrm{~g}$ chicken feathers and $50 \mathrm{ml}$ chromium solution each were sealed at specified temperature until equilibrium was obtained. The adsorbents were separated by filtration. Adsorbate concentrations were measured by spectrophotometric methods. Blank solutions, without adsorbent, were similarly treated to account for any losses in chrome concentration by time due to other reasons than adsorption. The concentration of the blank solution after the equilibrium time was taken as being the initial concentration (Co). The difference between the initial concentration ( $\mathrm{Co}$ ) and the equilibrium concentration (Ce) per unit mass $(\mathrm{m})$ of adsorbent was used to compute the amount of chromium removed (qe) in $\mathrm{mg} / \mathrm{g}$ from its solution using the relation:

$$
\mathrm{q}_{\mathrm{e}}=[0.05(\mathrm{Co}-\mathrm{Ce})] / \mathrm{m}
$$




\section{3-Results and Discussion}

\section{Contact time}

Figure 1 shows the influence of time on Cr (VI) adsorption. It's clear that time has evident influence on the adsorption during the first three hours. Beyond three hours the increase in adsorption is very small, therefore, an adsorption time of 5 hours could be considered as almost sufficient to reach equilibrium.

\section{Effect of pH:}

Table 1 gives the influence of $\mathrm{pH}$ on the adsorption behavior. The experiments were conducted using $50 \mathrm{ppm}$ chromium solution and $0.1 \mathrm{~g}$ chicken feathers. The amount of chromium adsorbed $\left(\mathrm{q}_{\mathrm{e}}\right)$ was found to increase with increasing $\mathrm{pH}$ from 1 to 2 , reaching a maximum, then decreases by increasing $\mathrm{pH}$ from 3 to 6 . This indicates that the solution $\mathrm{pH}$ affects the $\mathrm{Cr}$ (VI) adsorption. An acidic solution of a $\mathrm{pH}$ value from 1 to 2 is an optimal condition for the adsorption of $\mathrm{Cr}$ (VI). This last observation can be explained by the wellknown reduction of hexavalent chromium to its tri-form within this low range of $\mathrm{pH}$ value [29].

Table i. Influence of ph on chromium adsorption.

\begin{tabular}{|c|c|c|c|c|c|c|c|}
\hline PH & 1 & 2 & 3 & 4 & 6 & 7 & 9 \\
\hline $\begin{array}{c}\text { Amount adsorbed q } \\
\mathrm{mg} / \mathrm{g}\end{array}$ & 7.39 & 8.9 & 6.69 & 5.03 & 3.8 & Unfeasible \\
\hline
\end{tabular}

\section{Adsorption isotherms:}

Figure 2 depicts the adsorption isotherm measured for chicken feathers at $25{ }^{\circ} \mathrm{C}$. Three isotherm models were tested these are: Langmuir, Freundlich and Redlich - Peterson isotherms. The first isotherm, Langmuir, whose linear form is represented by:

$$
\mathrm{C}_{\mathrm{e}} / \mathrm{q}_{\mathrm{e}}=1 / \mathrm{K}_{\mathrm{L}}+\left(\mathrm{a}_{\mathrm{L}} / \mathrm{K}_{\mathrm{L}}\right) \mathrm{C}_{\mathrm{e}}
$$

can be graphically represented by a linear plot of $\mathrm{C}_{\mathrm{e}} / \mathrm{q}_{\mathrm{e}}$ against $\mathrm{C}_{\mathrm{e}}$. Figure 3 suggests the applicability of the Langmuir isotherm for the present system, and demonstrate monolayer coverage of the Adsorbate at the outer surface of the adsorbent [30]. Values of $K_{L}$ and $a_{L}$ were determined from the Langmuir plot and found to be 1.436 and $0.176 \mathrm{dm}^{3} / \mathrm{mg}$ of chromium respectively. The value of constant $\left(\mathrm{K}_{\mathrm{L}} / \mathrm{a}_{\mathrm{L}}\right)$ represent the maximum adsorption capacity. The essential characteristics of Langmuir isotherm can be expressed in terms of a dimensionless constant separation factor or equilibrium parameter, R [31], which is defined by:

$$
\mathrm{R}=1 /\left(1+\mathrm{a}_{\mathrm{L}} \mathrm{C}_{\mathrm{e}}\right)
$$

The equilibrium parameter $(\mathrm{R})$ indicates the shape of the isotherm as follows [31]:

\begin{tabular}{|l|l|l|l|l|}
\hline Value of $\mathbf{R}$ & $\mathbf{R}>\mathbf{1}$ & $\mathbf{R}=\mathbf{1}$ & $\mathbf{0}<\mathbf{R}<\mathbf{1}$ & $\mathbf{R}=\mathbf{0}$ \\
\hline Type of isotherm & Unfavorable & Linear & Favorable & Irreversible \\
\hline
\end{tabular}

The value of $(\mathrm{R})$ was found to be between 0 and 1 (0.1662) which indicates favorable adsorption of chromium on chicken feathers. 
The experimental data for adsorption have also analyzed using Freundlich isotherm given in the equation (4).

$$
\mathrm{q}_{\mathrm{e}}=\mathrm{K}_{\mathrm{f}} \mathrm{C}_{e}^{n}
$$

The equation may be linearized via a logarithmic plot which enables the exponent (n) and the constant $\left(\mathrm{K}_{\mathrm{f}}\right)$ to be determined which is:

$\log \mathrm{q}_{\mathrm{e}}=\log \mathrm{K}_{\mathrm{f}}+(1 / \mathrm{n}) \log \mathrm{C}_{\mathrm{e}}$

Plots of qe versus $\log \mathrm{C}_{\mathrm{e}}$ are shown in figure 4 where the results are represented by more than one straight line. The constant $\left(\mathrm{K}_{\mathrm{f}}\right)$ is a measure of adsorption capacity while $(\mathrm{n})$ the measure of adsorption intensity. Values of the constant $\left(K_{\mathrm{f}}\right)$ are $1.85 \mathrm{dm}^{3} / \mathrm{g}$ and $5.36 \mathrm{dm}^{3} / \mathrm{g}$ for the first and the second section of the plot while those values of (n) are 2.735 and 7.8 respectively. Value of (n) between 1 and 10 show favorable adsorption of chromium on chicken feathers [31]. The correlation coefficients for the linear regression of the Langmuir and Freundlich plots are found to be 0.9699 and 0.978 respectively.

Analysis of the results by linear form of Redlich- Peterson was carried out by the equation (6)

$$
\log \left\{\left[\left(\mathrm{K}_{\mathrm{RP}} \mathrm{C}_{\mathrm{e}}\right) / \mathrm{q}_{\mathrm{e}}\right]-1\right\}=\log \mathrm{a}_{\mathrm{RP}}+\beta \log \mathrm{C}_{\mathrm{e}}
$$

The plots of $\log \left\{\left[\left(\mathrm{K}_{\mathrm{RP}} \mathrm{C}_{\mathrm{e}}\right) / \mathrm{q}_{\mathrm{e}}\right]-1\right\}$ against $\log \mathrm{C}_{\mathrm{e}}$ are shown in figure 5 and can be considered to be linear, with a correlation coefficient of 0.9602 .

From the above results, it can be concluded that the correlation between the three isotherms from one side and the experimental data from the other side is reasonable in all cases.

\section{Adsorption kinetics:}

In a well-agitated batch adsorber, the concentration of Adsorbate in the liquid phase $\mathrm{C}_{t}$ and the concentration of adsorbent particles in the liquid $\mathrm{m}_{\mathrm{s}}$ are assumed to be uniform throughout the vessel. Consequently, $\mathrm{m}_{\mathrm{s}}$ may be determined from the measured mass of adsorbent $(\mathrm{m})$ and the volume of particle - free liquid (v) according to the equation:

$$
\mathrm{m}_{\mathrm{s}}=\frac{m}{v}
$$

If particles are assumed to be spherical, the surface area $\left(S_{\mathrm{s}}\right)$ of particles can be obtained from $\mathrm{m}_{\mathrm{s}}$ for mass transfer calculation as:

$$
\mathrm{S}_{\mathrm{s}}=\frac{6 m_{s}}{d_{p} \rho_{t} \cdot\left(1-\varepsilon_{p}\right)}
$$

Where $d_{p}$ can be calculated from the length of feather pieces, which ( if whose main branch is curved to be a circle) will form a particle shape whose surface is curved by a sub feather branches and thus the length of its main branch will form the perimeter of the considered 
particle shape. The change in chromium solution concentration $\left(\mathrm{C}_{\mathrm{t}}\right)$ with time is related to the fluid particle mass-transfer coefficient by the equation:

$$
\mathrm{d} \mathrm{C}_{\mathrm{t}} / \mathrm{dt}=-\mathrm{K}_{\mathrm{s}} \mathrm{S}_{\mathrm{s}} \quad\left(\mathrm{C}_{\mathrm{t}}-\mathrm{C}_{\mathrm{s}}\right)
$$

With $\quad \mathrm{C}_{\mathrm{t}}=\mathrm{C}_{\mathrm{o}}$ at $\mathrm{t}=0$

If effective diffusion coefficients are neglected, then, since $C_{s}$ approaches zero and $C_{t}$ approaches $\mathrm{C}_{\mathrm{o}}$ as $\mathrm{t} \rightarrow 0$, equation (9) becomes:

$$
\left[\frac{d\left(C_{t} / C_{o}\right)}{d t}\right]_{t=0}=\mathrm{K}_{\mathrm{s}} \mathrm{S}_{\mathrm{s}}
$$

\section{Effect of agitation:}

A series of experiments was undertaken to study the influence of agitation on the external mass transfer coefficient. The external mass transfer coefficient $\mathrm{K}_{\mathrm{s}}$ for different agitation speeds may be expressed by an equation of the general form:

$$
\mathrm{K}_{\mathrm{s}}=\mathrm{X}(\text { variable })^{\mathrm{Y}}
$$

or in the logarithmic form

$$
\log \mathrm{K}_{\mathrm{s}}=\log \mathrm{X}+\mathrm{Y} \log (\text { variable })
$$

Where the variable can be any of the agitating speed, size, or mass of chicken feathers. The experimental results for the effect of agitation on the adsorption of chromium are shown in figure 6 as a plot of $\left(\mathrm{C}_{\mathrm{t}} / \mathrm{C}_{\mathrm{o}}\right)$ against time for the adsorption of chromium on chicken feathers. The data show that the rate of chromium removal was influenced by the degree of agitation and the uptake increases with stirring rate. The results listed in table 2 and figure 7 indicate that external adsorption of chromium onto chicken feathers is affected by the degree of agitation; the effect of increasing agitation being to decrease boundary layer resistance to mass transfer and increase the mobility of the system [32 ]

\section{Effect of chicken feather length:}

The influence of length of chicken feather's pieces (size) has also been studied and the experimental results obtained are depicted in figure 8 as plot of $\left(C_{t} / C_{o}\right)$ against time for the adsorption of chromium onto chicken feathers. The external mass transfer $\left(\mathrm{K}_{\mathrm{s}}\right)$ have been determined (table 2) and these results have also been plotted as $\log \mathrm{K}_{\mathrm{s}}$ versus log length using equation (12).

The data in table 2 show that increasing feather's length results in a decrease in the external mass transfer coefficient $\mathrm{K}_{\mathrm{s}}$. This may be explained by the fact that smaller lengths move faster in solution than larger size ones and hence there are more shear on their surfaces.

\section{Effect of chicken feather mass:}

The effect of chicken feather mass on the adsorption rate has also been studied when keeping other experimental conditions constant. The results are shown in figure 10 as plot of $\left(\mathrm{C}_{t} / \mathrm{C}_{\mathrm{o}}\right)$ against time of adsorption of chromium onto chicken feathers. The data show an increase in the rate of chromium adsorption with increasing chicken feather mass. The external masstransfer coefficient, $\mathrm{K}_{\mathrm{s}}$ were determined using equation (12) as $\log \left(\mathrm{K}_{\mathrm{s}}\right)$ versus-log mass (figure 11). The resulting linear graph indicates that $\mathrm{k}_{\mathrm{s}}$ varied with chicken feather mass in a 
logarithmic manner. The values of constants $\mathrm{X}$ and $\mathrm{Y}$ for equation 12 is also determined and are listed in table 2.

The external mass -transfer coefficient depends on the driving force per unit area and in this case, since $C_{o}$ is constant, increasing the mass of feather increases the surface area for adsorption and hence, the rate of chromium removal is increased. For a constant feather length, the surface area will be directly proportional to the mass of chicken feathers in the system. The $\left(\mathrm{K}_{\mathrm{s}}\right)$ values shown in table 2 indicate a small dependence on mass, since $\left(\mathrm{K}_{\mathrm{s}}{ }^{)}\right.$ decreases with increasing mass of feather. This effect is probably due to the fact that for small masses a small amount of external surface is available for adsorption of chromium; despite there are being a large driving force from chromium per unit surface area of chicken feathers [29, 32-34].

Table II: External Mass Transfer Coefficient $\mathrm{K}_{\mathrm{S}}$ for Different System Variables (A, B, C)

Table II A: Agitation Speed

\begin{tabular}{|l|l|l|l|l|l|}
\hline Agitation speed $(\mathrm{rpm})$ & 400 & 700 & 900 & $\mathrm{X}$ & $\mathrm{Y}$ \\
\hline $\mathrm{K}_{\mathrm{s}} * 10^{3}$ & 1.137 & 4.69 & 6.17 & $6.725^{*} 10^{-9}$ & 2.03 \\
\hline
\end{tabular}

Table II B: Length

\begin{tabular}{|l|l|l|l|l|l|l|}
\hline length $(\mathrm{cm})$ & 0.5 & 1.0 & 1.5 & 2.0 & $\mathrm{X}$ & $\mathrm{Y}$ \\
\hline $\mathrm{K}_{\mathrm{s}} * 10^{3}$ & 2.04 & 1.85 & 1.7 & 1.47 & $-1.806 * 10^{-3}$ & -0.2126 \\
\hline
\end{tabular}

Table II C: Mass

\begin{tabular}{|l|l|l|l|l|l|l|}
\hline Mass $(g)$ & 0.85 & 1.7 & 3.4 & 4.25 & $\mathrm{X}$ & $\mathrm{Y}$ \\
\hline $\mathrm{K}_{\mathrm{s}} * 10^{3}$ & 4.3 & 3.9 & 3.42 & 3.02 & $4.28 * 10^{-3}$ & -0.209 \\
\hline
\end{tabular}

\section{4- Conclusions}

The experimental results from laboratory-scale studies indicate that chicken feathers have the ability to adsorb considerable quantities of chromium. Removal of hexavalent chromium is highly $\mathrm{pH}$ dependent, the best results where obtained at 1 and 2 values for the $\mathrm{pH}$ of the solution. The adsorption of chromium is assumed to be governed by the reduction of $\mathrm{Cr}$ (VI) into $\mathrm{Cr}$ (III) and subsequently by the formation of surface complexes. Adsorption isotherms have been determined and the data obtained were analyzed using Langmuir, Freundlich and Redlich- Peterson isotherms. The correlation between three isotherms and experimental data was reasonable in all cases. The variable affecting the external transport of chromium from water onto chicken feathers have been studied and correlated against the external masstransfer coefficient, $\mathrm{K}_{\mathrm{s}}$, by a mathematical relation. By a log-log correlation, it has been proved that the external mass-transfer coefficient varies linearly with agitation, size and mass of chicken feathers . 


\section{5-Nomeclature}

$a_{L} \quad$ Parameter of Langmuir isotherm $\left(\mathrm{dm}^{3} / \mathrm{mg}\right)$

$a_{R P} \quad$ Parameter of Redlich-Peterson isotherm $\left[\left(\mathrm{dm}^{3} / \mathrm{mg}\right)^{1-\beta}\right]$

$\mathrm{C}_{\mathrm{e}} \quad$ Equilibrium liquid-phase concentration $\left(\mathrm{mg} / \mathrm{dm}^{3}\right)$

$\mathrm{C}_{\mathrm{o}} \quad$ Initial liquid-phase concentration $\left(\mathrm{mg} / \mathrm{dm}^{3}\right)$

$\mathrm{C}_{\mathrm{s}}$ liquid-phase chromium concentration at particle surface $\left(\mathrm{mg} / \mathrm{dm}^{3}\right)$

$\mathrm{C}_{\mathrm{t}} \quad$ liquid-phase chromium concentration at time $\mathrm{t}\left(\mathrm{mg} / \mathrm{dm}^{3}\right)$

$d_{p} \quad$ Feathers particle size ( diameter calculated from the length of the feather pieces) $(\mu \mathrm{m})$

$\mathrm{K}_{\mathrm{F}} \quad$ Parameter of Freundlich isotherm $\left(\mathrm{dm}^{3} / \mathrm{g}\right)$

$\mathrm{K}_{\mathrm{L}} \quad$ Parameter of Langmuir isotherm $\left(\mathrm{dm}^{3} / \mathrm{g}\right)$

$\mathrm{K}_{\mathrm{RP}} \quad$ Parameter of Redlich-Peterson isotherm $\left(\mathrm{dm}^{3} / \mathrm{g}\right)$

$\mathrm{K}_{\mathrm{s}} \quad$ External mass transfer coefficient $(\mathrm{cm} / \mathrm{s})$

M Mass of feathers in the adsorber $(\mathrm{g})$

$\mathrm{m}_{\mathrm{s}} \quad$ Mass of feathers per unit volume of feathers - free solution $\left(\mathrm{g} / \mathrm{dm}^{3}\right)$

$\mathrm{N} \quad$ Freundlich exponent ( dimensionless)

$\mathrm{q}_{\mathrm{e}} \quad$ Equilibrium solid - phase concentration (mg/g)

$\mathrm{R} \quad$ Dimensionless equilibrium parameter, defined by equation (4)

$\mathrm{S}_{\mathrm{s}} \quad$ Outer surface area of clay particle per unit volume of particle - free solution $\left(\mathrm{cm}^{-1}\right)$

$\mathrm{T} \quad$ Time (min)

$\mathrm{N} \quad$ Volume of chromium solution $\left(\mathrm{dm}^{3}\right)$

$\mathrm{X} \quad$ Pre-exponential constant, defined by equation (13)

Y Exponential factor, defined by equation (13)

$\beta \quad$ Redlich- Peterson exponent (dimensionless)

$\varepsilon_{\mathrm{p}} \quad$ Porosity of feathers texture (dimensionless)

$\rho_{\mathrm{t}} \quad$ True density $\left(\mathrm{g} / \mathrm{cm}^{3}\right)$ 


\section{Refrences}

[1] T. Pansward, O. Chavalpairt, V. Sucharittham, W. S. Choroen, A bench-scale study on chromium recovery from tanning waste water, Water Science and Tech. 31 (1995) $73-81$.

[2] M. Tomaselli, D. Castiello, Use of Chromium hydroxide recovery by precipition as an oxidizing agent (in leather industry), Cuoio Pelli . Mater . Concianti.57 (1981) 255 268.

[3] Pollution Control Department, The ministry of natural resources and environment, Water quality standards (2005).

[4] M. N. Evans, Yi-Tin. Wang, Hexavalent chromium reduction by bacillus Sp. In a paced-bed bioreactor, Environ. Sci. Techno. 31 (1997) 1446-1451.

[5] C. A. Jackson - Mass, J. R. Duncan, the effect of trivalent Chromium on anaerobic digestion, J.Amer Leather .Chem . Assoc. 83 (1988) 389-395.

[6] Yi-Tin Wang, Hai Shen, Modelling Cr(VI) by pure bacterial cultures, Water Research 31 (1997) 727-732.

[7] D. C. Sharma,C. F. Forster, Removal of hexavalent Chromium using sphagnum mass peat, Water Research 27 (1993) $1201-1208$.

[8] R. K. Srivastav, S. K. Gupta, D. P. Nigam, P.Vausudevan ,Treatment of chromium and nikel in wastewater by aquatic plants, Water Research , 28 (1994)1631-1638.

[9] K. S. Low, C. K. Lee, A. Y. Kg, Chromium (VI) adsorption on quaterinzed rice hulls, J.Environ.Sci Health, A 32 (1997) 1849-1860.

[10] R. M. Schneider, C. F. Cavalin, M. A. S. D. Barros, C. R. G. Tavares, Adsorption of chromium ions in activated carbon, Chem. Eng. J. 132 (2007) 355-362.

[11] O. D. Cooney, Adsorption deign for waste water treatment, Lewis publishers (1999).

[12] A. M. Youssef. Th. El-Nabarawy, S. E. Samra, Sorption properties of chemically activated carbon, 1. Sorption of cadmium (II) ions, Colloids Surf. 235 (2004) 153-163.

[13] K. Selvi, S. Pattabhi, K. Kadirvelu, Removal of $\mathrm{Cr}(\mathrm{VI})$ from aqueous solution by adsorption onto activated carbon, Bioresour. Technol. 80 (2001) 87-89.

[14] M. Grover, M. S. Narayanswamy, Removal of hexavalent Chromium by adsorption on fly ash, J. Environ. Eng. 63 (1982) 36-39.

[15] Cho. Heechan, Oh. Dalyoung, Kim Kwanho, A study on removal characteristics of heavy metals from aqueous solution by fly ash, J. Hazard. Mater. 127 (2005) 187-195.

[16] M. Ahmedna, W.E. Marshall,R.M. Rao, Production of granular activated carbon from select agricultural by-product and evaluation of their physical, chemical and adsorption properties,Bioresour. Echnol.71 (2000) 113-123.

[17] N. Kannan, A Vanangamudi, A study on removal of chromium (VI) by adsorption lignite coal, Ind. J. Environ. Pollut. 11 (1991) 241-245.

[18] S. Chand, V. K. Agarwal, C. Pavankumar, Removal of hexavalent chromium from wastewater by adsorption, Ind. J. Environ. Health 36 (1994) 151-158.

[19] K. Srinivasan, N. Balasubramaniam, T. V. Ramakrishna, Studies on chromium removal by rice huck carbon, Ind. J. Envitron. Health 30 (1988) 376-387. 
[20] P. A. Brown, S. J. Allen, Metal removal from wastewater using peat, Wat. Res. 34 (2000) 3907-3916.

[21] V. K. Gupta, M. Gupta, S. Sharma, Process development for removal of lead and Chromium from aqueous solutions using red Mud-an aluminum industry waste, Water Res. 35 (2001) 1125-1134.

[22] M. A. Hossain, M. Kumita, Y. Michigami, S. Mori, Kinetics of Cr(VI) adsorption on used black tea leaves, J. Chem. Eng. Japan 38 (2005) 402-406.

[23] N. F. Fahim, B. N, Barsoum, A. E. Eid, M. S. Khalil, Removal of chromium (III) from tannnery wastewater using activated carbon from sugar industrial waste, J. Hazard Mater. 136 (2006) 303-309.

[24] N. A. Khan, H. Mohamed, Investigation on the removal Chromium (VI) from wastewater by sugarcane bagasse, Water and wastewater Asia (2007) 37-41.

[25] S. Bosinco, J. Roussy, E. Guibal, P. Xlecloirec, Interaction mechanisms between hexavalent cromium and corn cob, Environ. Technol. 17 (1996) 55-62.

[26] R. Dorowolski, E. Stefaniak, Study of Chromium (VI) adsorption from aqueous solutions onto activated carbon, Adsorption Sci and Technol. 18 (2000) 97-106.

[27] S. Moz, K. Ravindra, N. R. Bishoni, Adsorption of chromium from aqueous solution by activated alumina and activated carbon, Bioresource Technol. 98 (2007) 954-957.

[28] M. Kobya, Adsorption, Kinetic and equilibrium studies of $\mathrm{Cr}(\mathrm{VI})$ by hazelnut shell activated carbon, Adsorb. Sci. Technol. 22 (2004) 51-64.

[29] F. A. Banat, S. Al. Asheh, The use of column packed with chicken feathers for the removal of phenol from aqueous solutions, Ads. Sci. Techol. 19 (2001) 553-563.

[30] M. S. El-Geundi, Adsorption equilibria of basic dyestuffs onto maize cob, Adsp. Sci. Technol. 7 (1990) 114-123.

[31] D. Ruthern, M. Goddard, Fundamentals of adsorption, American Institute of chem. Eng . New york (1984).

[32] M. S. El-Geundi, Adsorption kinetics of cationic dyestuffs onto natural clay, Adsor. Sci. Technol. 13 (1996) 265-303.

[33] D. Aggarwal, M. Goyal, R. C. Banal, Adsorption of chromium by activated carbon from aqueous solution, Carbon 37 (1990) 1989-1997.

[34] O. A. Fadali, E. E. Ebrahiem, Y. H. Magdy, A. A. M. Daifullah, M. M. Nssar, Removal of Chromium from tannery effluents by adsorption, J. Environ. Sci. Health..part A Environ. Sci. Eg. 9 (2005) 465-472. 
Fig. 1. Effect of Time on Equilibrium Isotherm for Chromium onto Chicken Feathers

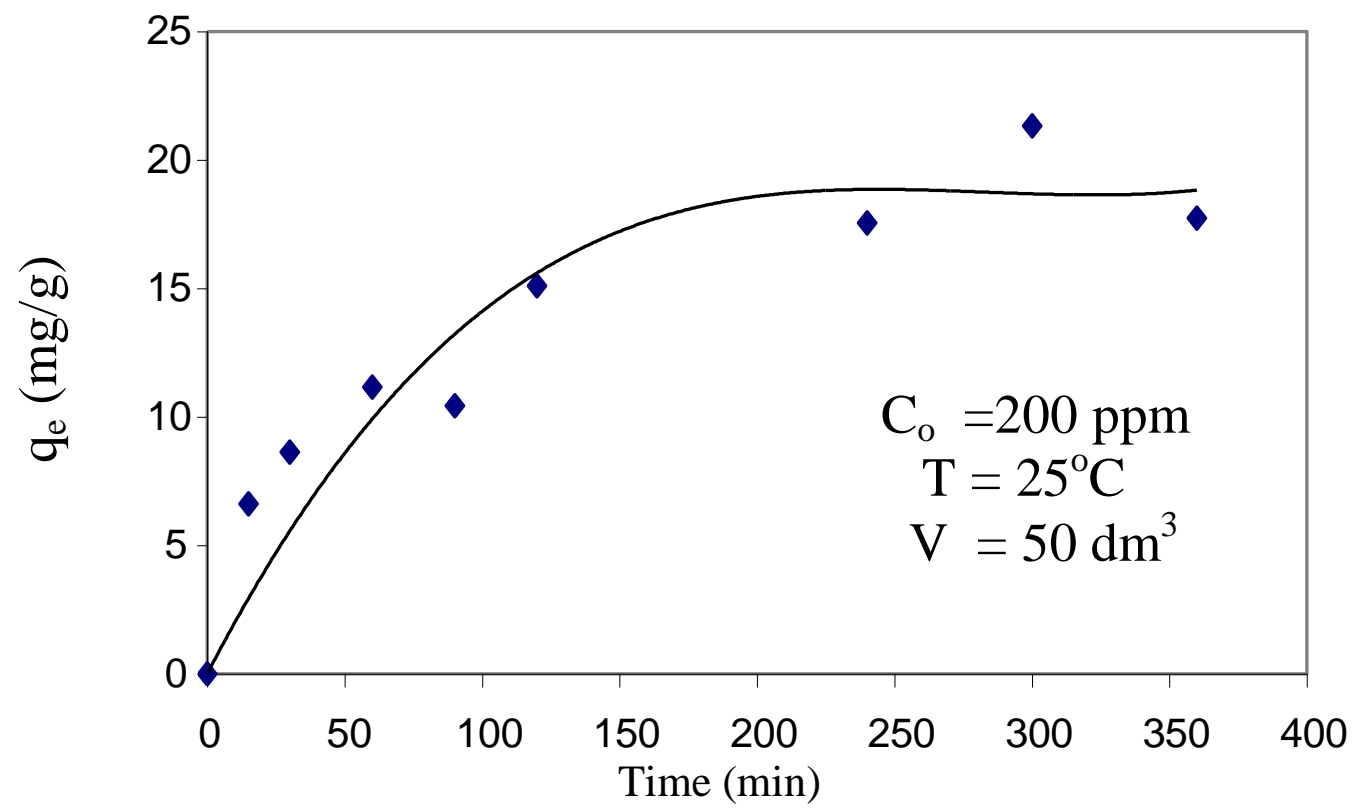

Fig. 1. Effect of Time on Equilibrium Isotherm for Chromium onto Chicken Feathers

Fig. 2. Adsorption Isotherm for Chromium onto Chicken Feathers

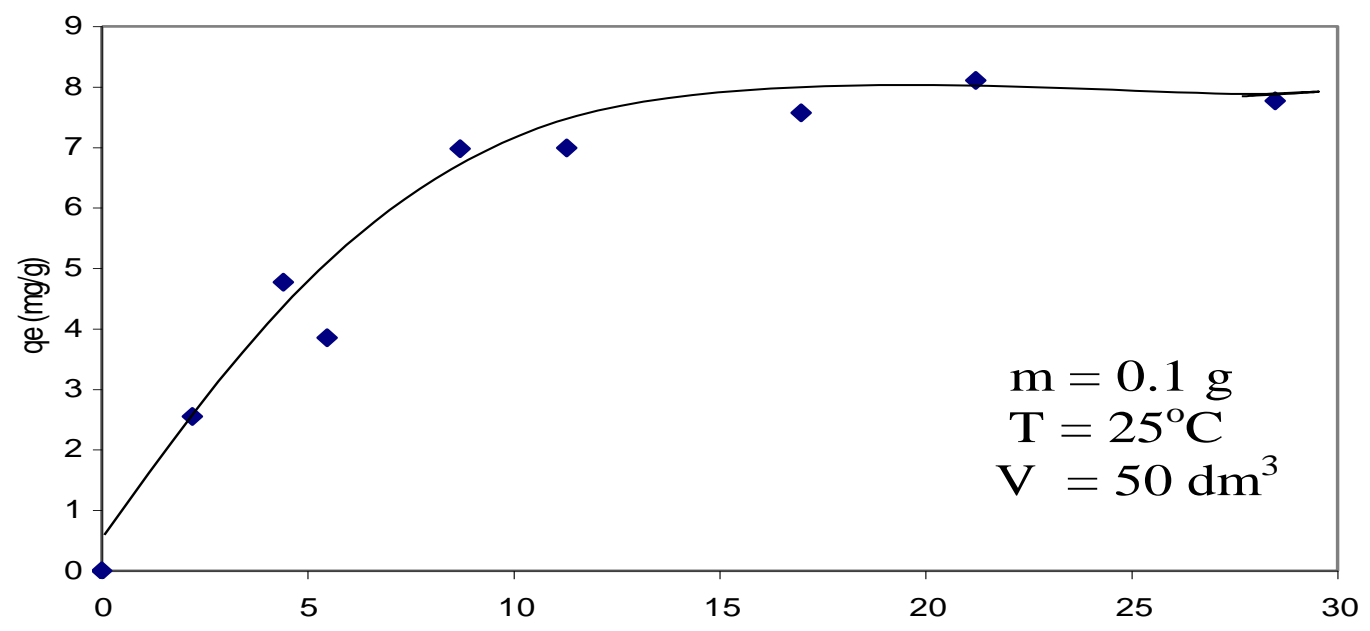

Fig. 2. Adsorption Isotherm for Chromium onto Chicken Feathers 
Fig. 3. Langmuir Plot for Adsorption of Chromium onto Chicken Feathers.

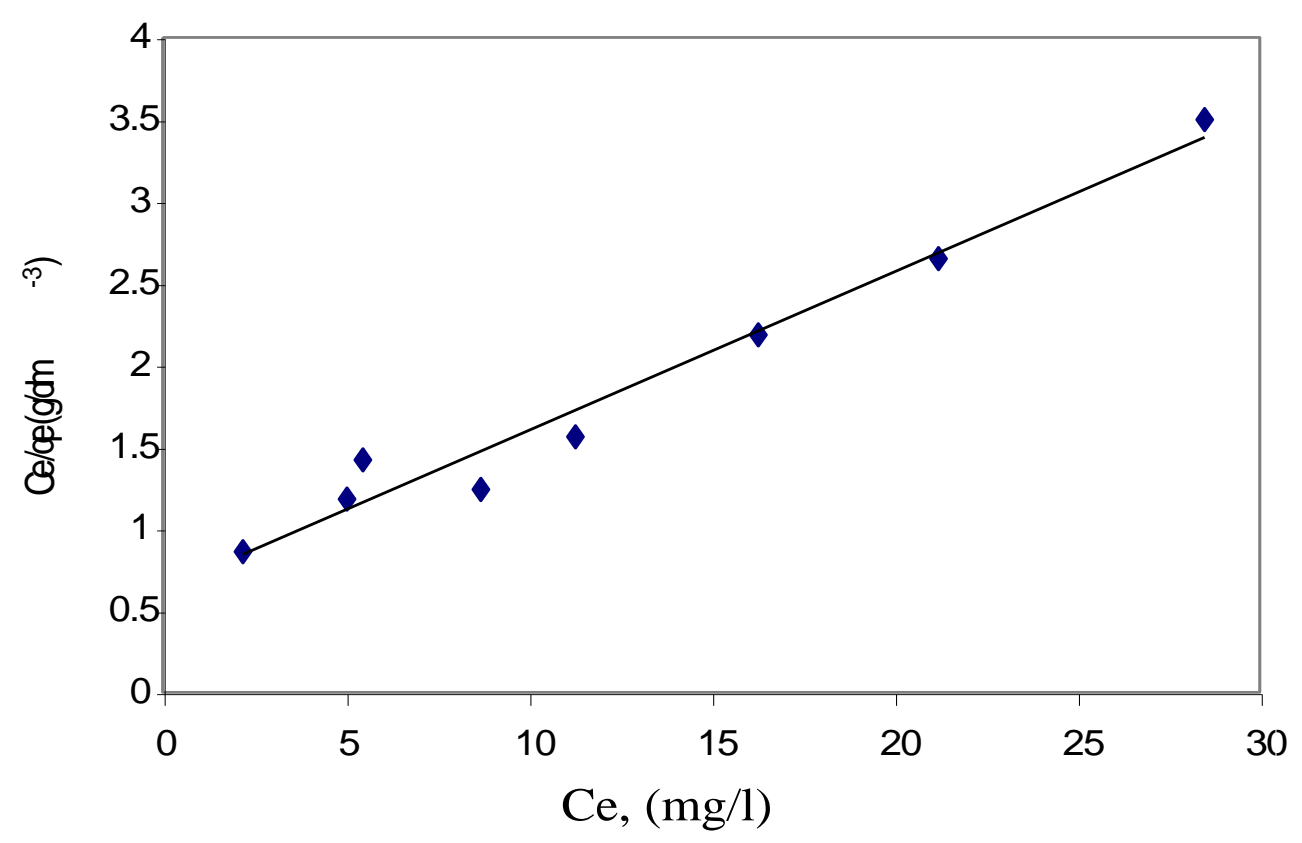

Fig. 3. Langmuir Plot for Adsorption of Chromium onto Chicken Feathers.

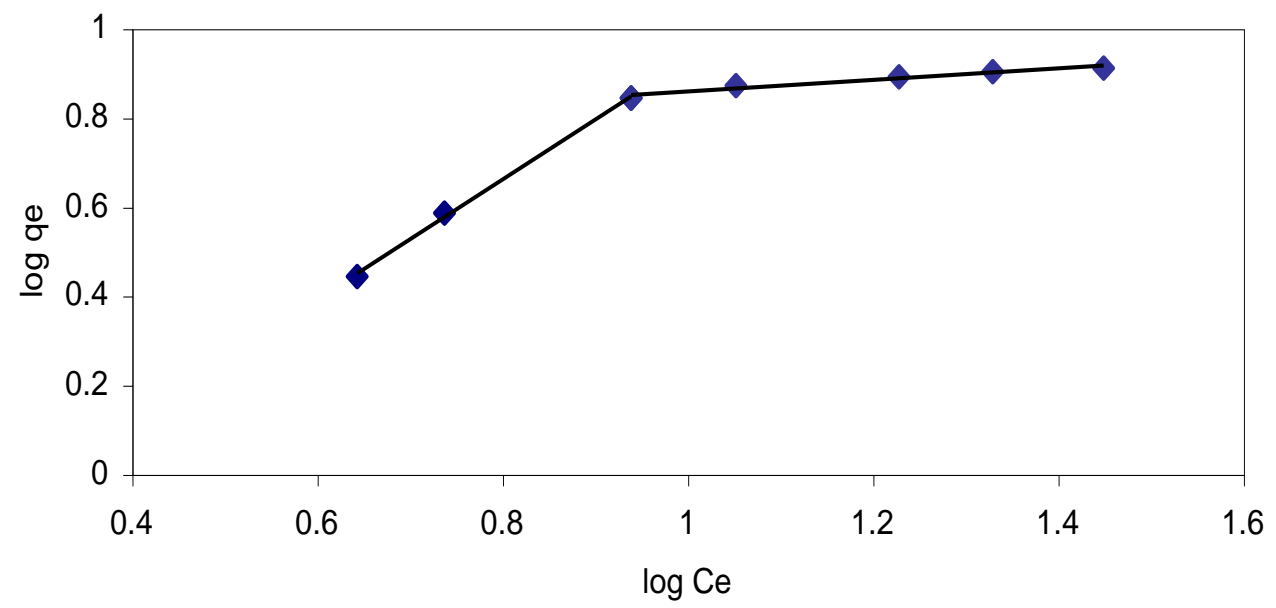

Fig. 4. Freundlich Plot for Adsorption of Chromium onto Chicken Feathers 


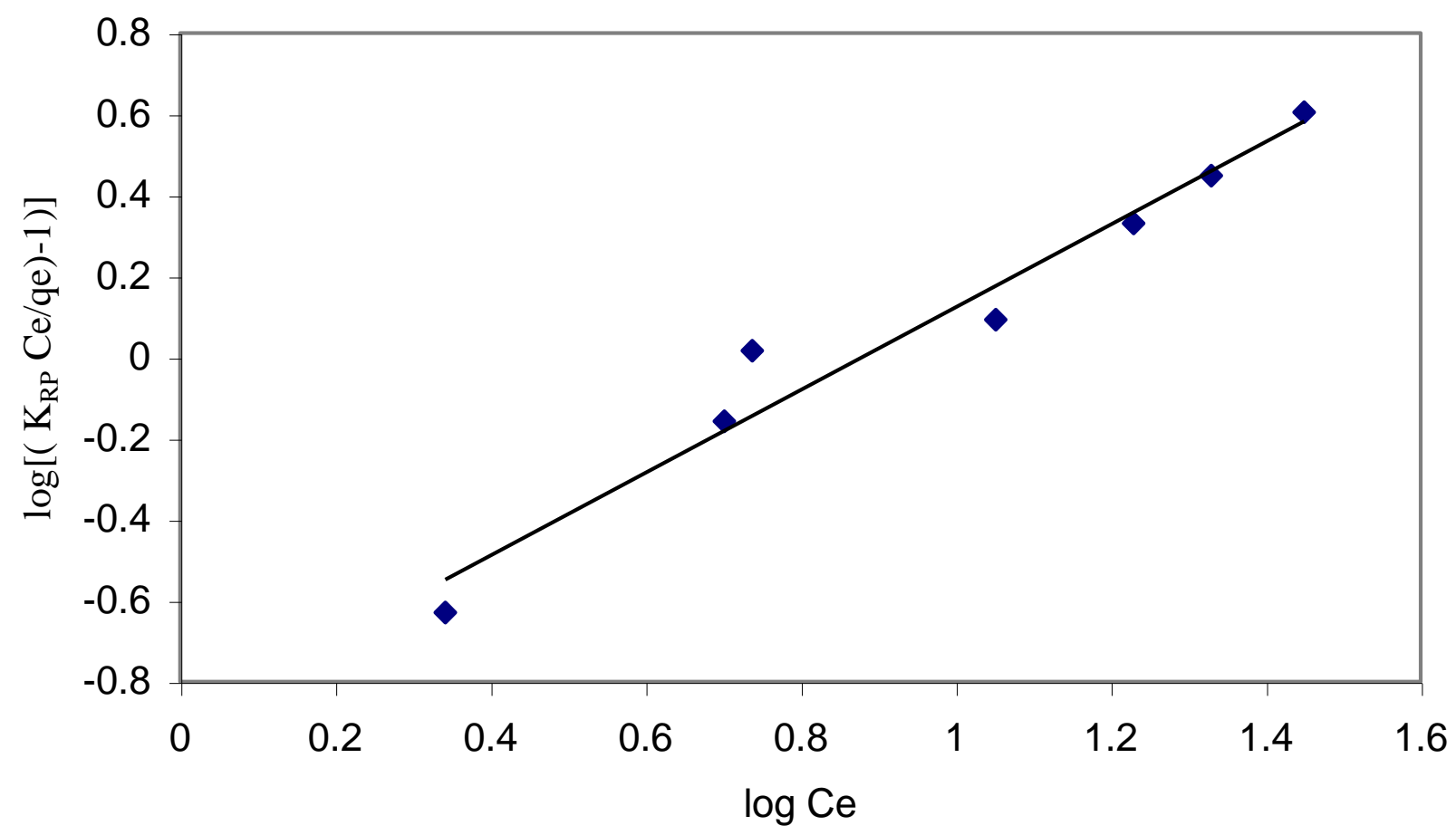

Figure 5: Redlic-Peterson Plot for Adsorption of Chromium onto Chicken Feathers

Fig. 6. Effect of Agitation on the Adsorption of Chromium onto Chicken Feathers

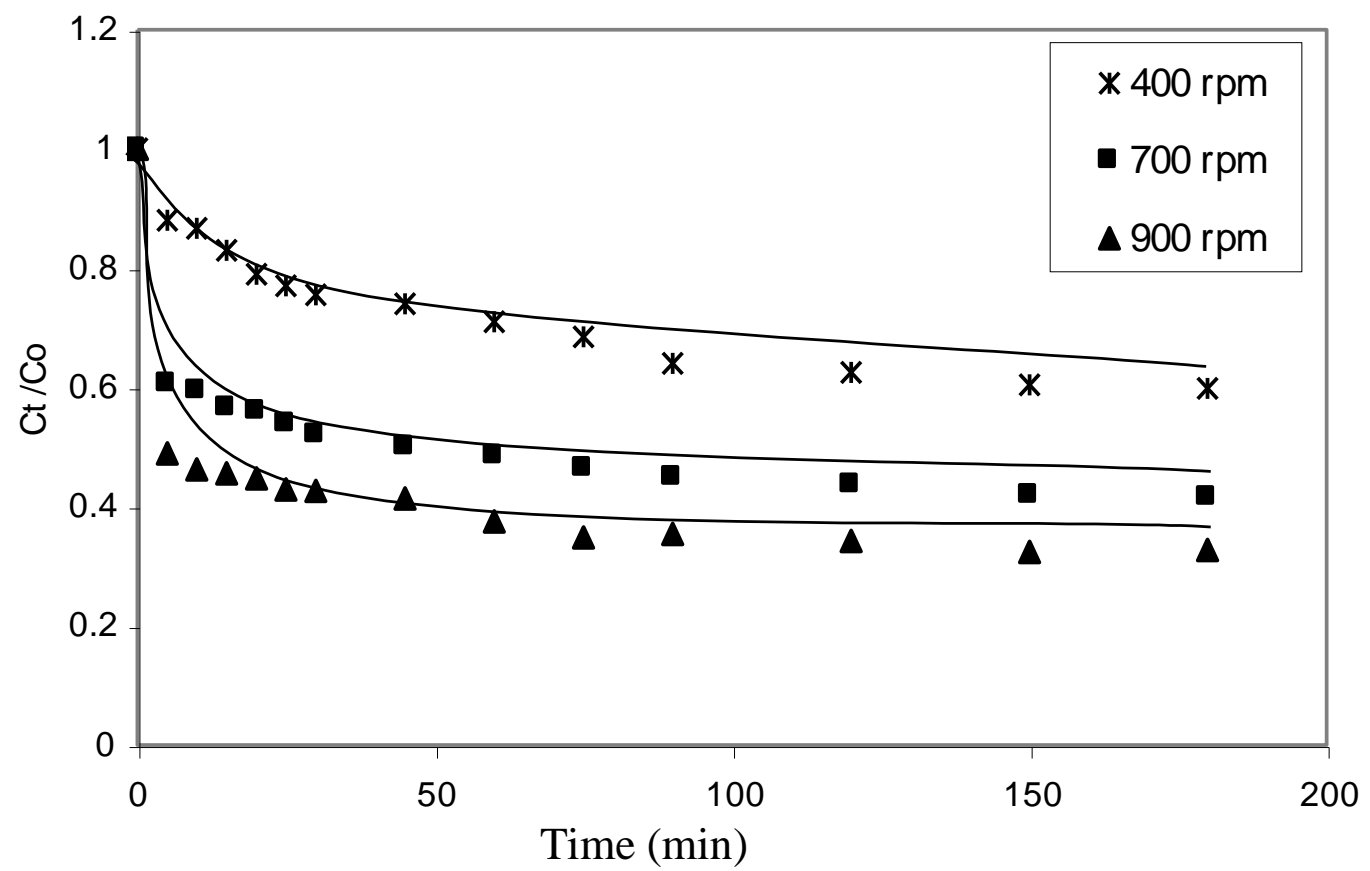

Fig. 6. Effect of Agitation on the Adsorption of Chromium onto Chicken Feathers 
Fig. 7. Plot of ks Versus log rpm for the Adsorption of Chromium onto Chicken Feathers

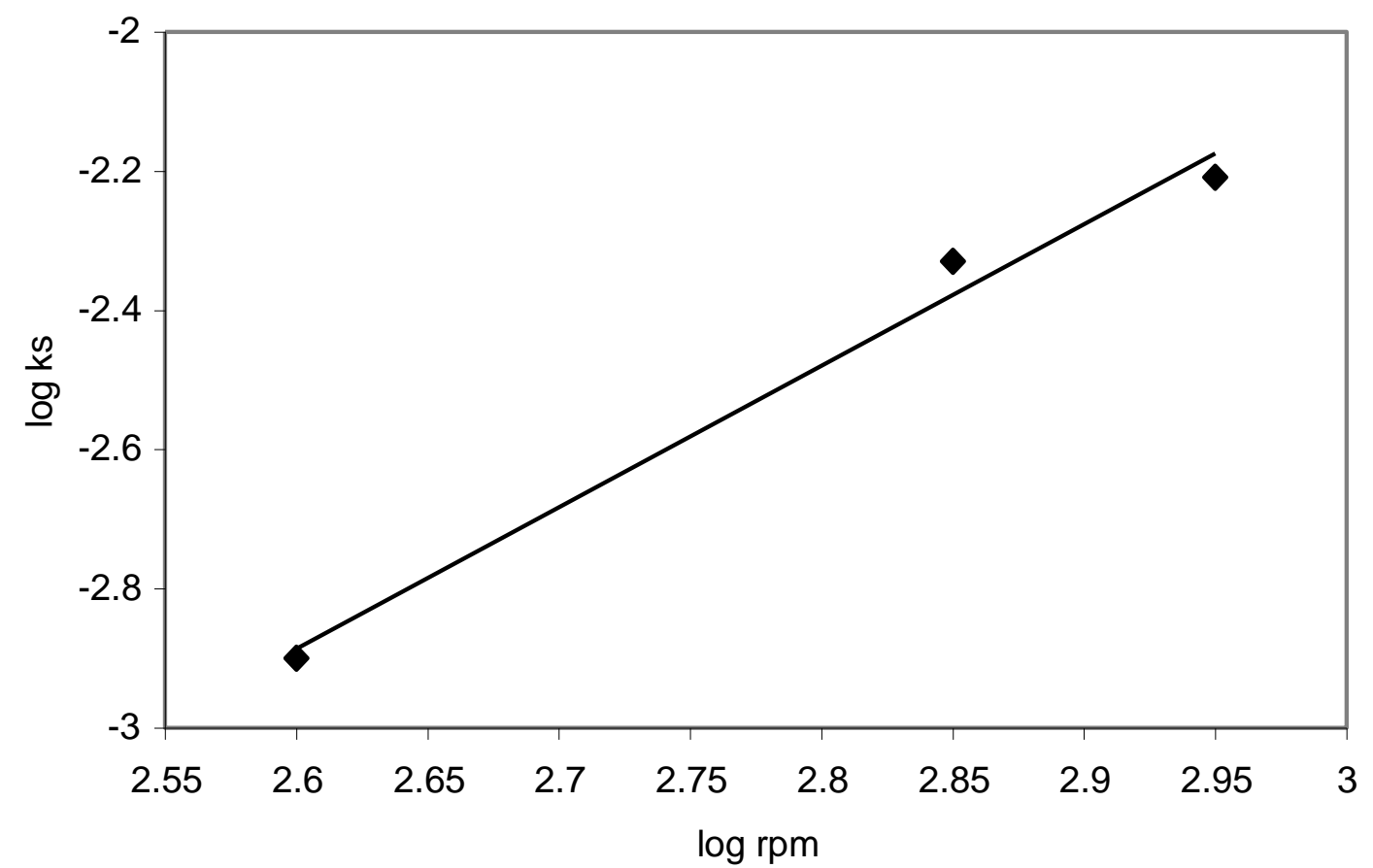

Fig. 7. Plot of ks Versus log rpm for the Adsorption of Chromium onto Chicken Feathers

Fig. 8. Effect of Length on the Adsorption of Chromium onto Chicken Feathers

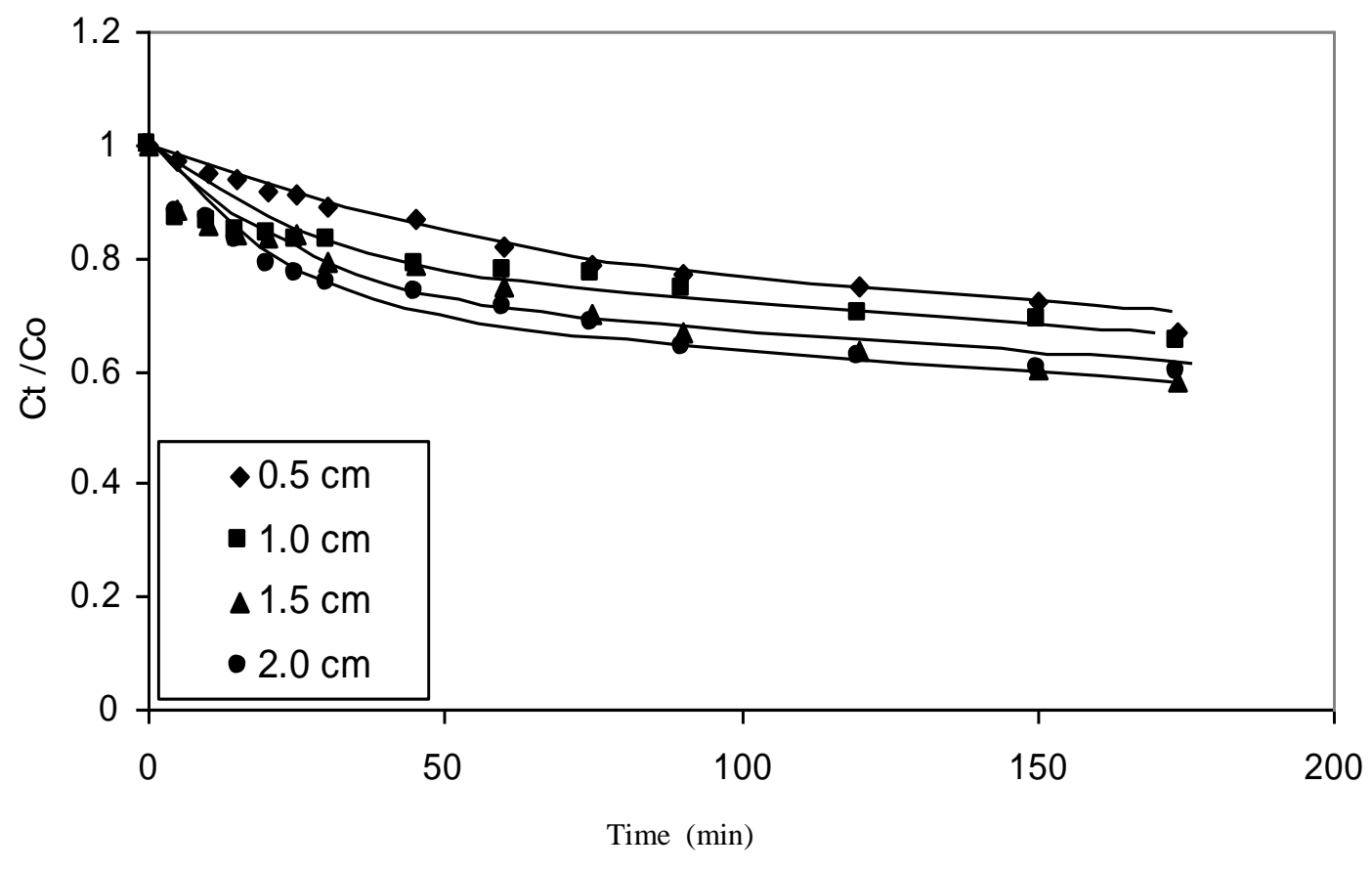


Fig. 9. Plot of log ks Versus log Length for the Adsorption of Chromium onto Chicken Feathers

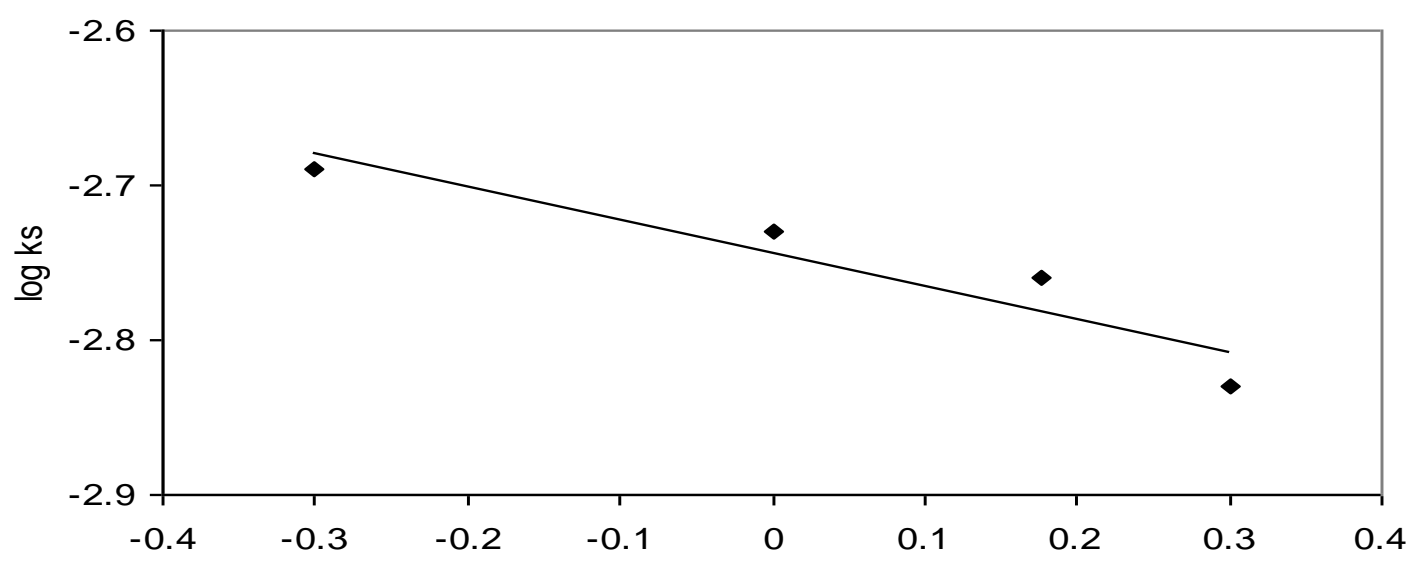

$\log$ length

Fig. 10. Effect of Mass of Chicken Feathers on the adsorption of Chromium

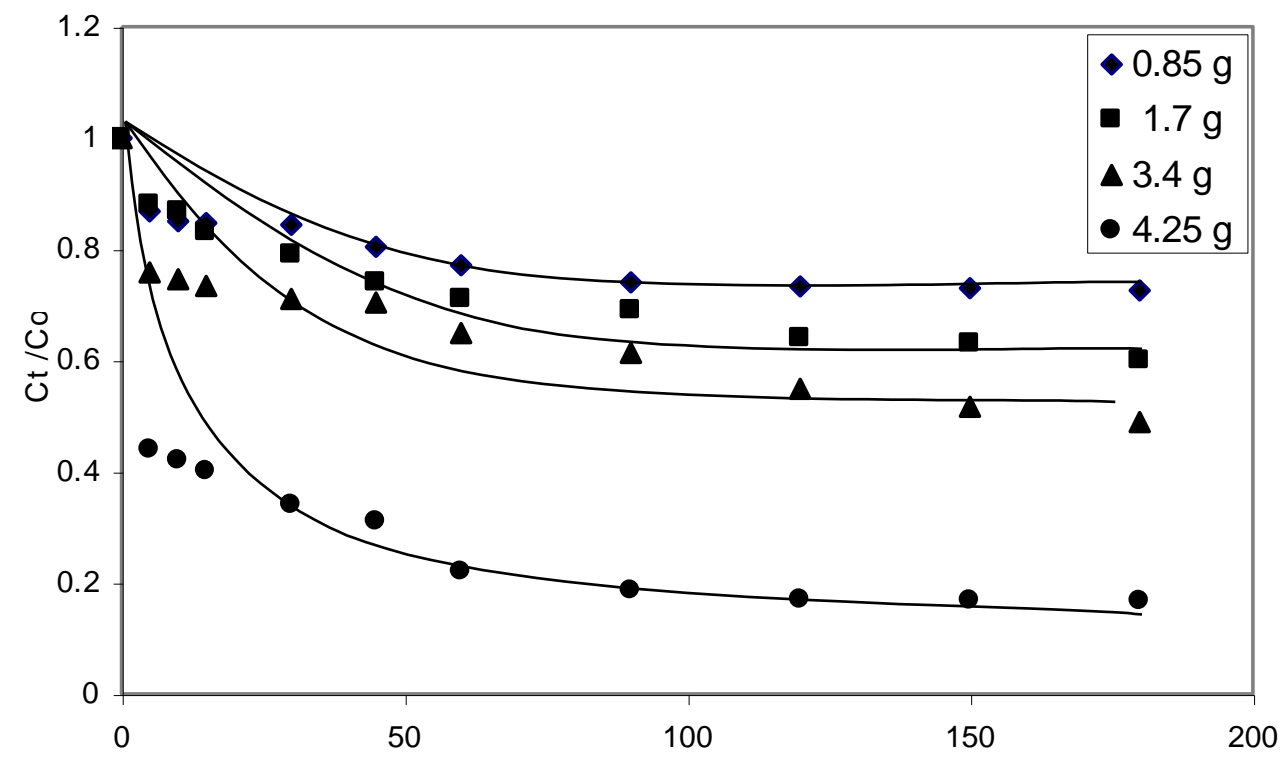


Fig. 11. Plot of log ks Versus log Mass for the Adsorption of Chromium onto Chicken Feathers.

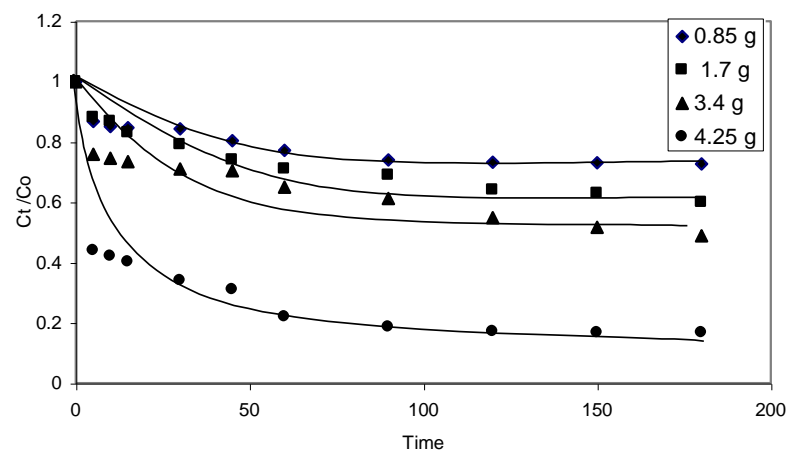

Time (min) 